\title{
PROTEIN METABOLISM IN INFANTS AND CHILDREN *
}

HERMAN SCHWARZ, M.D.

NEW YORK

Before going into a general description of nitrogen metabolism it is of the utmost importance to get a general idea of the newer facts known in regard to protein bodies. Protein bodies represent a highly complex organic combination which has become better known through the studies of Hochmeister, Kossel, and especially of Emil Fisher.

The researches of Emil Fisher, Abderhalden, Bergel, Rona and others show that the end-products of the proteins, are the amino-acids obtained by hydrolysis, and are bodies of the normal fat and aromatic series in which the $\mathrm{H}$ atom is displaced by an $\mathrm{NH}_{2}$ group. Of these acids many varieties have been described, of which the better known are glycocoll, alanin, tyrosin, valin, Ieucin and isoleucin. Whereas the carbohydrate (glycogen) of the body represents combinations of a definite chemical group, the glucoses, and the fats a combination of glycerin and fatty acids, the proteins on the other hand represent many combinations of these amino-acids. We do not as yet classify the proteins by their amino-acid content, if I may use that expression, but according to external properties. Thus we have:

Simple protein bodies.

Complex protein bodies.

The simple protein bodies include the albumins, globulins and the coagulable protein of muscles. These constitute the greater part of the protein in our food and bodies and are what we refer to when we talk off-hand of proteins.

The second group includes mucin, which has a carbohydrate radical attached; the nucleo-albumins, which have a phosphorus group as, for example, milk; hemoglobin, which has an iron group attached, and finally those complex albumins which really perform the functions of our lives, the albumin in the nuclei of the cells, the nucleoproteins, which are made up of purin bodies, phosphorus and carbohydrate groups.

When all these different proteins are ingested, they are split and hydrolyzed by the various ferments in a definite and regular manner. The pepsin reduces them to albumoses and peptones. The end-products (the amino-acids) are not present in the stomach at all or in but small quantities, for pepsin has the property of splitting up the protein body

*Read at the meeting of The American Pediatric Society, Lake Mohonk, May 31, 1911. 
into these more elementary substances only when they are allowed to remain in contact many hours.

It is the trypsin of the pancreatic juice, and especially the erepsin of the small intestines, by which these bodies are further split up ultimately into the amino-acids. In the course of this transition there is a period when they are not amino-acids, nor yet peptones or albumoses. In this stage they have been called by Emil Fisher polypeptids and he has actually been able by many combinations of amino-acids to manufacture polypeptids. The end-products of the breaking up of the protein molecule are the amino-acids. The number of these acids is considerable, and it is very likely that there are many combinations and thus many different kinds of proteins of which we have not the least idea. The proteins are absorbed in the form of amino-acids and their combinations. The body has actually been kept in nitrogen balance or even in a plus balance by means of feeding experiments with aminoacids. ${ }^{1}$ These amino-acids have also been found in the tissues of the body and serous cavities. ${ }^{2}$ The proteins, then, are split up by means of ferments into their ultimate component parts, the amino-acids, then absorbed into the body to be reconstructed into various substances and excreted by the kidneys in the form, principally, of urea and ammonia. As yet the intermediary metabolism, the interval between the absorption of the amino-acids from the intestines and their excretion in the urine and feces, contains many a dark spot which needs further investigation. It is to the end-products which as yet are our only guide that I wish to draw attention in this cursory discussion of the nitrogen metabolism in infants and children.

I shall first diseuss the total nitrogen, a consideration of the intake necessary at the various ages, and the nitrogen balance. In discussing this question one must first distinguish between the nitrogen metabolism in the breast fed and in the artificially fed, and above all, not forget to distinguish between the healthy and the sick infant.

A discussion of the metabolism of the breast-fed child is the most satisfactory and easiest, for by comparing the cases in the literature one is certain that the food given was more or less the same, namely breast milk, whereas in the artificially fed one has the difficulty in correlating different percentages of the various food elements, the different quantities taken, and the uncertainty that one is dealing with normal children.

If we take a number of cases of breast-fed babies (see Table 1) from the literature, as Czerny and Keller and Orgler ${ }^{2}$ did, adding some of our own, and observe the amount of nitrogen taken in, we will be immedi-

1. Schittenhelm and Frank: Ztschr. f. physiol. Chemie, 1909, lxiii, 215.

2. Umber: Lehrbuch der Ernährung und Stoffwechselkrankheiten, 1909, Urban and Schwarzberg. 


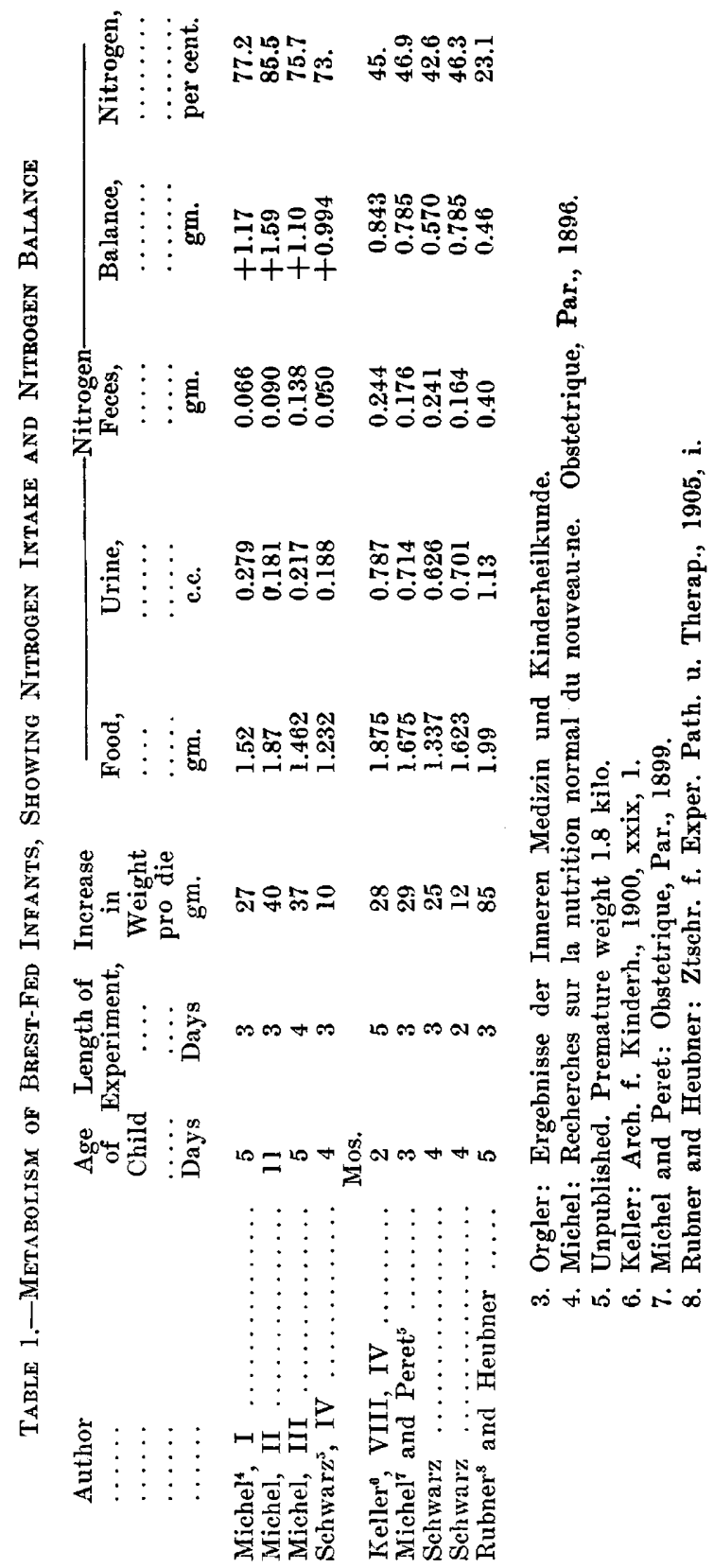


ately struck with the fact that irrespective of the age, the amounts taken in are about the same.

Thus the 3-months-old child of Michel and Peret or the 4-months-old child of Schwarz does not even take as much as the 11-days-old child of Michel, but in contrast to this, the nitrogen in the urine excreted in this 11-days-old child is $0.181 \mathrm{gm}$. as compared with 0.714 of Michel and Peret and 0.626 of Schwarz. The intake then is about the same but the output is distinctly different, not alone in the urine but also in the feces. The retention is seen to decrease and the output to increase as the infant grows older.

In order to make a comparison of various cases in the literature we must have certain data to go by. These are (1) the amount retained per kilogram body weight per day and (2) the percentage retained as compared with the amount taken in. This latter is called the utilization figure. The first alone would not be sufficient, for if we gave the infant too little, naturally the retention would be too small. A comparison of utilization alone would give us an incorrect picture, for if we gave too much nitrogen, even though a great amount of nitrogen be retained, the utilization would appear small.

It is only by a combination of the amount retained per kilo a day and the utilization, that a proper idea of nitrogen metabolism may be obtained. If these children are arranged according to their ages (see Table 2) and the amount of nitrogen taken in and retained per kilo weight, it will be seen that the amount of nitrogen retained is quite independent of the amount taken in.

Table 2.-Amounts of Nitrogen Taken in and Retained according to Ages

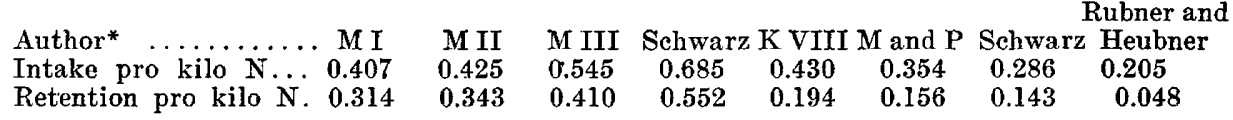

*The cases are the same as those referred to in Table 1.

If we compare K VIII with M II we see that with similar intake we have $194 \mathrm{mg}$. retained in one instance and $343 \mathrm{mg}$. in the other. If we compare the amount retained and their ages it will be seen that the amount of retained nitrogen is dependent on the age, so that a 14-daysold child retains the most and the 5-months-old child the least. Therefore the amount of nitrogen per kilogram weight required in infancy is apparently about the same, but the amount retained and its proportion to the amount taken in, is according to the age.

Grouping a number of these cases roughly together according to age as shown by Orgler, ${ }^{3}$ we have an excellent idea of the utilization of nitrogen in infancy.

$\begin{array}{lccc}\text { Age } \ldots \ldots \ldots \ldots & \text { Up to } 14 \text { Days } & 2 \text { to } 3 \text { Months } & 5 \text { Months } \\ \text { Retention } \ldots \ldots & 0.351 & 0.153 & 0.048 \\ \text { Utilization } \ldots \ldots & 78.3 & 40.8 & 23.1\end{array}$




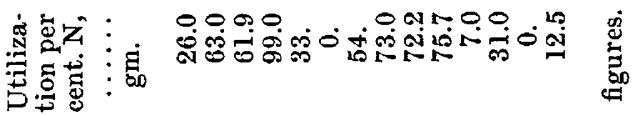

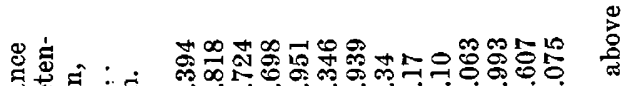

出出

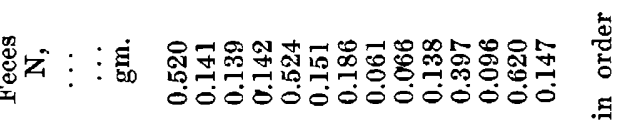

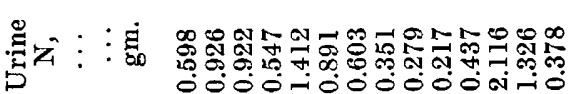

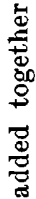

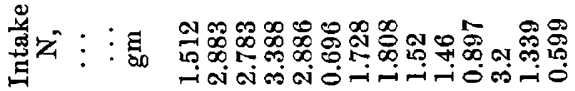

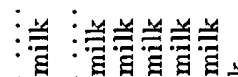

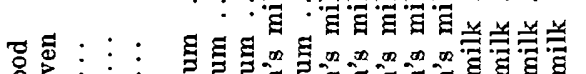

(2)

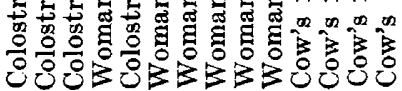

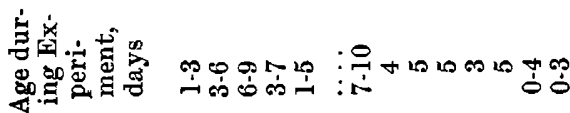
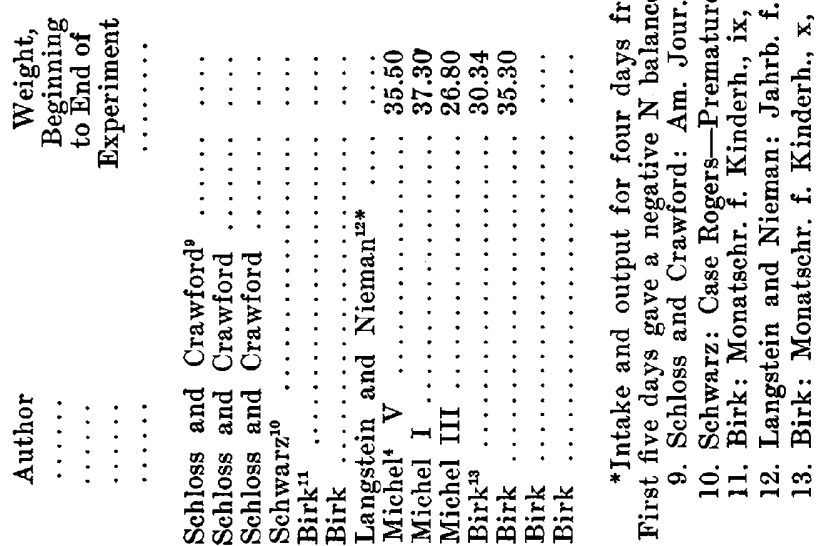
The nitrogen metabolism of the first few days of life shows such distinctive characteristics that I have deemed it better to discuss this separately and collect the available material in one table. Langstein and Nieman showed that there is a negative nitrogen balance during the first few days when the baby is fed on woman's milk pumped from a well-established lactating breast. In their first case the balance was negative for the first four days; in the second case for the first two days; third case for the first two days, and in the fourth case, a premature baby, it was negative for the first eight days of life. In an infant of Schloss and Crawford's, fed on colostrum, the intake of nitrogen was $1.5 \mathrm{gm}$., and about $1.1 \mathrm{gm}$. was excreted in the urine and feces, with a utilization of 26 per cent. Schwarz' case, that of a premature infant, beginning from the third day up to the seventh day of life, can hardly be brought under this heading, for it was not controlled from birth. It was fed on woman's milk and showed a retention of over $2.0 \mathrm{gm}$. of nitrogen during this time, and a utilization of 77 per cent.

Birk's patient-Case I-was fed on colostrum in a five days' experiment, during which there was a physiologic loss from $3,980 \mathrm{gm}$. to $3,760 \mathrm{gm}$. In spite of this there was a retention of $0.951 \mathrm{gm}$. nitrogen, a utilization of 33 per cent. In a second case there was a retention of nitrogen from the second day of life. His third patient, fed on woman's milk from birth, showed a loss of nitrogen. We see here an interesting physiologic fact, that with a loss of weight there may be a retention of nitrogen in the patients fed on colostrum, and a loss of nitrogen when fed on woman's milk. This shows the value of colostrum, for in Langstein's case this loss is ascribed to a breaking down of protein in the tissues. In two of Birk's patients fed on cow's milk the results varied somewhat, for in Case I there was a loss of $606 \mathrm{mg}$. of nitrogen and in the second case a retention of $75 \mathrm{mg}$. of nitrogen. The utilization of the nitrogen in the cases in this table differs somewhat from the general rule given by Orgler previously in being considerably less. This is in part due to the fact that in some of the cases the first few days with low utilization of nitrogen are included with the later days of higher utilization, as might have been done if Schloss' periods had not been separated as shown in the tables. Thus, in the first three days the utilization was 26 per cent.; then 63 per cent., which is nearer to the figures obtained by Michel and Peret. Birk ascribes the low utilization in the babies fed on cow's milk to the large excretion of nitrogen in the urine, which in Michel's cases was one-sixth and one-seventh of the intake, while in the cow's milk babies it was as high as two-thirds of the intake. This he regards as a fundamental difference between the two types of feeding. Yet in Schloss' case during the first three days, 30 per cent. of the nitrogen intake was excreted in the urine, and in Birk's Case I, fed 
on colostrum, 50 per cent. of the nitrogen appeared in the utilization. From the foregoing it is clear that nitrogen utilization in the new-born needs considerable more investigation.

Before taking up the nitrogen metabolism of the artificially-fed child, it is important to know the effect in the same child of increasing the various food elements in the mixture.

As shown above, in the breast-fed child the amount of nitrogen excreted in the urine is not constant and is of no value except as compared with the intake, being 11 per cent. in Michel's ${ }^{4}$ 5-days-old child, and 42 per cent. in Michel and Peret's ${ }^{7} 3$-months-old child. So also the amount of nitrogen in the stools, in the breast and artificially fed varies according to the age and the character of the food. The stools present a special problem, for here the nitrogen may be derived from the food, the intestinal secretions, bacteria or epithelium. The nitrogen content of the stool can be increased by changing the character of the food, thus causing an increased secretion, or perhaps poor assimilation or resorption of the food nitrogen. Because nitrogen is added to the food and an increased amount of nitrogen is excreted in the stools, does not necessarily mean that this nitrogen came from the food, for there may have been more intestinal secretion, epithelium or bacteria excreted. In Schlossman's case Kriesch, as quoted by Orgler, ${ }^{14}$ the child excreted $1.22 \mathrm{gm}$. nitrogen in the feces, with an intake of $6.5 \mathrm{gm}$. of nitrogen, whereas with an intake of $10.05 \mathrm{gm}$. nitrogen, excreted only $1.119 \mathrm{gm}$. Child $\mathrm{M}$ IV in Orgler's experiment ${ }^{15}$ excreted $0.62 \mathrm{gm}$. nitrogen in the feces with an intake of $8.1 \mathrm{gm}$. nitrogen. At another time this infant received $3.3 \mathrm{gm}$. nitrogen and excreted $0.61 \mathrm{gm}$. nitrogen, a difference of only $0.01 \mathrm{gm}$. nitrogen. In one of my experiments a breast-fed baby getting $1.6 \mathrm{gm}$. nitrogen excreted $0.164 \mathrm{gm}$. nitrogen in the stools; at another time receiving $1.25 \mathrm{gm}$. nitrogen, excreted $0.346 \mathrm{gm}$. or three times the former amount with the same intake. The amount of nitrogen in the food then has very little influence on the nitrogen in the feces.

In hunger there is always a small amount of nitrogen in the stools. A patient of Keller's, examined while on a water diet, excreted 0.0716 gm. nitrogen, or 7 per cent. of the dried feces. In Orgler's case ${ }^{15}$ the stools contained 5 per cent. nitrogen (dried feces). In my cases with an intake of $1.47 \mathrm{gm}$. nitrogen and an excretion of $0.15 \mathrm{gm}$. nitrogen in the stool, there was 4.5 per cent. nitrogen in the dried feces. In another instance with an intake of $1.252 \mathrm{gm}$. nitrogen there was an excretion of $0.346 \mathrm{gm}$. nitrogen in the feces, or 4.3 per cent. of the dried feces. This percentage of nitrogen (about 5 per cent.) to dried stool is fairly constant. If a nitrogen-free diet succeeds a water diet there will be an

14. Schlossman: Arch. f. Kinderh., 1904, xl, 1.

15. Orgler: Monatschr. f. Kinderh., 1908, p. 135. 
increase in nitrogen in the feces. What is most interesting is, that if a little flour, which in itself contains but very little nitrogen, is added to nitrogen-free food, there will be a great increase in the nitrogen excretion in the feces. Such an instance is a case of Rubner and Heubner. ${ }^{10}$ With a diet of flour containing $1.02 \mathrm{gm}$. nitrogen there was $0.45 \mathrm{gm}$. nitrogen in the stools-almost 50 per cent. of the intake. Therefore, as shown by Orgler, the resorption or the difference between the nitrogen intake and that found in the stools is of very little value, and an increase of protein in the food may have no effect on the nitrogen of the feces.

In the adult when in health and taking the proper amount of food there is just a nitrogen balance, but in infancy, in health, there is a marked retention. This is the great difference in their nitrogen metabolisms, for the latter is a growing organism and needs its nitrogen for its increase in weight and growth. It is very difficult to bring an infant into a state of nitrogen equilibrium, in which he will be excreting as much as he takes in. This can be done by reducing the protein intake sufficiently. This will, however, cause a diet to be given which is calorically entirely below the requirements necessary to retain weight. If we proceed now to add protein, the infant will immediately begin to retain nitrogen, although the food values may be very much below the required amount. This explains the phenomenon of nitrogen retention and no gain in weight. The infant adds to its growth and not to its weight.

To illustrate the effect of the addition of fat to the food, I reproduce in part a table of Orgler's (Table 4).

Table 4.-Showing the Effect on Nitrogen Balance of the Addition of FAT TO THE FOOD

\begin{tabular}{|c|c|c|c|c|c|}
\hline $\begin{array}{l}\text { Food } \\
\cdots \\
\cdots \\
\cdots \\
\text { Tr }\end{array}$ & $\begin{array}{c}\text { Nitrogen } \\
\text { in Food, } \\
\text {... } \\
\text { gm. }\end{array}$ & $\begin{array}{c}\text { Urea } \\
\text { N, } \\
\cdots \\
\text { gm. }\end{array}$ & $\begin{array}{l}\text { Feces } \\
\mathrm{N}, \\
\ldots \\
\text { gm. }\end{array}$ & $\begin{array}{l}\text { Bal- } \\
\text { ance, } \\
\text { gm. } \\
\text { gm. }\end{array}$ & $\begin{array}{l}\text { Nitrogen } \\
\text { utili- } \\
\text { zation } \\
\text { per cent. } \\
19.6\end{array}$ \\
\hline Freund I., ${ }^{17}$ Buttermilk $\ldots$ & 3.389 & 2.446 & 0.278 & 0.665 & $\begin{array}{l}19.6 \\
19.4\end{array}$ \\
\hline $\begin{array}{l}\text { Buttermilk and butter } \ldots . . \\
\text { L. F. Meyer, }{ }^{18} 200 \text { c.c. milk, } \\
800 \text { c.c. barleywater, } 16.5\end{array}$ & 3.047 & 2.144 & 0.311 & 0.592 & \\
\hline $\begin{array}{l}\text { gm. casein, } 20 \text { gm. sugar. } \\
20.0 \mathrm{gm} \text {. same and butter } \ldots\end{array}$ & $\begin{array}{l}3.55 \\
3.6296\end{array}$ & $\begin{array}{l}1.799 \\
1.93\end{array}$ & $\begin{array}{l}0.256 \\
0.202\end{array}$ & $\begin{array}{l}1.417 \\
1.45\end{array}$ & $\begin{array}{l}42.2 \\
40 .\end{array}$ \\
\hline
\end{tabular}

From Table 4 it will be seen that when buttermilk alone is given, with a nitrogen content of 3.387 gm. there is a utilization of 19.6 per cent. If butter is added, we have the same utilization of nitrogen. L. F. Meyer's ${ }^{18}$ case illustrates the same thing. So that we may conclude that the addition of fat to the food does not save nitrogen and the utilization is the same.

16. Ztschr. f. Biol., 1899, xxxviii, 315 .

17. Freund: Zur Wirkung der Fettdarreichung auf dem Säuglingsstoffwechsel, Jahrb. f. Kinderh., 1905, lxi, 36 .

18. L. F. Meyer: Biochem. Ztschr., 1908, xii, 422. 
The influence of carbohydrates on the nitrogen metabolism is very marked. From Table 5 it will be seen that when a mixture one-half each of milk and water is given, the child retains $0.2 \mathrm{gm}$. of nitrogen with a utilization of 9.9 per cent. and on giving the same mixture with the addition of malt in the form of malt-soup we have a retention of $0.4 \mathrm{gm}$. of nitrogen and a utilization of 17 per cent. This action of the carbohydrates, however, does not work in instances in which the children do not stand sugar well, as shown in an experiment on Orgler's Baby $0,{ }^{19}$ in which the addition of sugar caused a marked loss of nitrogen. The saving of nitrogen by sugar is caused partly by the fact that the child does not need to draw on its protein if it has plenty of sugar.

Table 5.-(From Orgler). Nitrogen Balance and Nitrogen Utilization ox Diets of Milk and Water and Malt-Soup

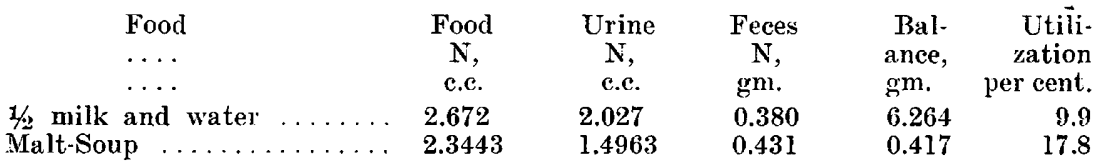

This cannot be the only cause, for it can be shown that if a very small amount of barley diluent is added instead of water the retention is increased out of all proportion to the very slight increase of carbohydrate and nitrogen in the barley. The utilization is also markedly increased. Just what this is due to is not known.

The relation of the mineral metabolism to the nitrogen metabolism, according to Orgler, is fairly constant. Designating the amount of ash retained as 1.0, the relation of nitrogen to ash will be seen in Table 6 , taken from Orgler.

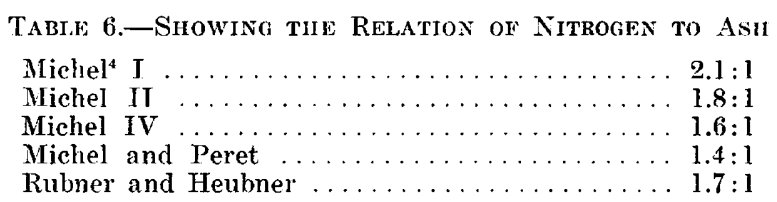

This is not the case in artificially fed infants and is especially important in sick children, for whenever alimentary disturbances occur there is a marked divergence from the above.

In a consideration of the nitrogen metabolism of the healthy artificially fed, all the above-mentioned factors must be taken into consideration and one must be sure that the child is absolutely healthy and gaining weight regularly. It is important in the first instance to be oriented concerning the utilization and intake with breast and artificial feeding in the same child in order to determine whether the utilization of

19. Orgler: Jahrb. f. Kinderh., 1908, lxvii, 383. 


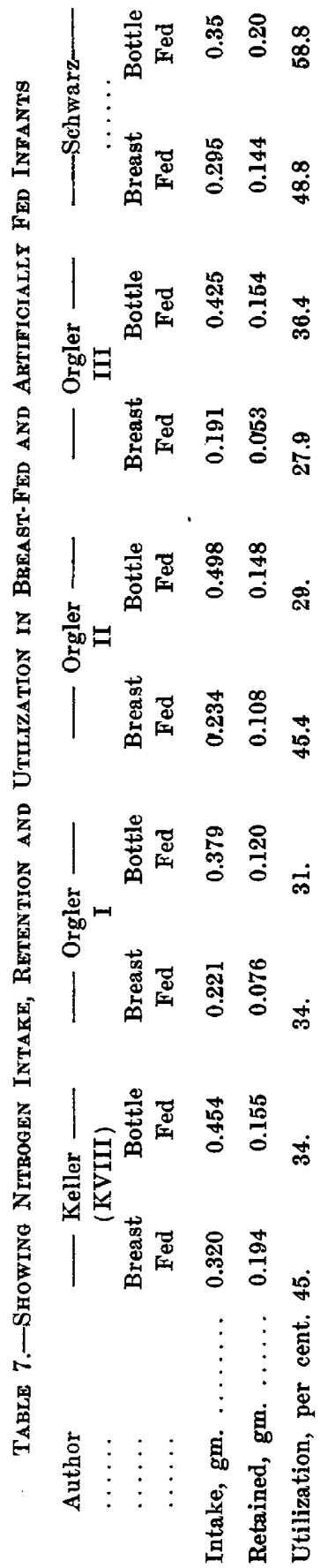


nitrogen is the same or better in the one method of feeding than the other. For this purpose Orgler has three cases in sick infants and only one in a healthy breast baby. To this we can add one case in a breast child which was apparently healthy, and was used because its mother had a nephritis and was excreting large quantities of albumin in her urine. The infant also had a faint trace of albumin.

In Table 7 these cases are tabulated. It was unfortunate that in Keller's case the child while on the bottle did not get enough calorically, yet the utilization was almost as good as when on the breast. In comparing Orgler's Case III and Schwarz' case it will be seen that the retention and utilization while on cow's milk may even be better than with breast milk if the artificial feeding is properly conducted. In a comparison of healthy bottle babies to other breast babies of the same age it can be said that the retention and utilization is at least as good. The resorption is also as good in artificial feeding as in the breast feeding, as shown in a case of Orgler' ${ }^{20}$ in which an infant getting five feedings a day of woman's milk had resorption of 74.8 per cent. of intake; on two feedings of breast milk and three of cow's milk the resorption was 78.3 per cent. and on a cow's milk mixture calorically sufficient the resorption was 82 per cent.

In the sick infant, the conditions in breast or artificially fed infants are harder to compare, for here the unit of comparison, the kilo, is usually less than in normal children of the same age, and this fact necessitates a comparison with younger children. It is remarkable how much nitrogen these infants will retain while in their convalescence from intestinal disturbances. This pertains also to the artificially-fed child.

Orgler's ${ }^{21}$ conclusions concerning nitrogen utilization might well be repeated.

1. Healthy artificially-fed infants show similar or even better figures of nitrogen retention than healthy breast-fed babies of the same age.

2. Retention in the sick artificially-fed child is as good as in the sick breast-fed child.

3. Healthy infants often show better figures for retention when given a proper cow's milk mixture than on the breast.

4. The utilization of nitrogen may be as good or even better in the artificially fed than in the breast fed.

Let us consider for a moment how the functions of nitrogen differ in the adult and in the child.

1. Nitrogen repairs waste; makes good the daily wear and tear of the protein constituents of the tissues, used up in the performance of

20. Orgler: Monatschr. f. Kinderh., 1908, vii, 135.

21. Orgler: Ergebnisse der inneren Medizine und Kinderheilkunde, ii, 509. 
their functions. Of course this is equally important to both child and adult, but in the latter it constitutes most of its utility, and in arranging the adult dietary the protein need which shall subserve this function is alone imperative. In infants this minimum protein need, on account of reasons given before, cannot be accurately determined, but in some experiments it seems to run from 0.2 to $0.45 \mathrm{gm}$. nitrogen during the first fourteen days of life. In an older child a nitrogen equilibrium was struck when given $0.9 \mathrm{gm}$., being furnished with sufficient calories for its needs by the addition of carbohydrates.

2. Nitrogen adds to the body substance. This deposit or storage of nitrogen plays a secondary rôle in adults, but in children is of prime importance. In adults, under usual conditions, nitrogen is not stored. Any excess administered is split up, burned and eliminated. Only in the hypertrophy of muscles put to special activities, in pregnancy, in convalescence from wasting diseases and after prolonged fasting does such a deposit obtain. In infants and growing children a large part of the nitrogen ingested is added to the body bulk in response to the imperative demand of the impulse of growth. So insistent is this demand that an infant can store nitrogen even when the calories of the food are insufficient. This fact accounts for the common observation that a child will increase in length, though the gain in weight is not essential. In an adult a diet of insufficient caloric value leads to protein loss.

3. The third function of protein is to furnish heat and energy to the body. The heat value of protein is about the same as that of the carbohydrates. Each gram of either substance when completely combusted gives rise to 4.1 calories.

It is not, however, a function for the performance of which the human body looks to protein, but rather to fat and carbohydrates. Moreover, it is not an economical form of fuel when so used, owing to what is termed its "specific dynamic action," some 28.6 per cent. of its value is given off as free heat, leaving only 71.4 per cent. available for the purposes of cell life.

In infants this function of protein plays a small part, especially in natural feeding.

In early life, then, protein is used to repair waste; then to be stored to the limit of the storage capacity of the body; then to furnish energy and be eliminated in the urine.

The sparing of nitrogen built into the body and the storage of nitrogen brought to the body are greatly influenced by the constitution of the food as a whole. Indeed, the art of feeding in infancy, and quite as much in morbid conditions in adult life, depends on this appreciation of the effect of one food stuff on another in the metabolism of each. 
As previously stated, the protein taken in is reduced to its ultimate amino-acids, then built up again and excreted mostly in the form of urea and ammonia. It is to a discussion of these, as they make up a part of the total nitrogen in the urine, that we will now turn our attention. It is customary to quote the figures of various constituents of the nitrogen (nitrogen partitions) in the urine, in two ways: first, in actual milligrams excreted in twenty-four hours, and secondly in the amount of each substance as compared with the total amount of nitrogen in the urine.

This urea nitrogen and the ammonia nitrogen constitute the largest part of the nitrogen in the urine. These again, subtracted from the total nitrogen, leave a residue which was previously commonly called the undetermined nitrogen. This undetermined nitrogen is becoming more and more subdivided as we discover new methods of determining quantitatively the products of protein metabolism. At present it can be subdivided into the uric acid nitrogen, purin body nitrogen, creatinin and creatin nitrogen. When all these and the urea and ammonia nitrogen are subtracted from the total nitrogen in the urine, there is still a fraction which is in reality the undetermined nitrogen and is practically identical with the amino-acid nitrogen.

UREA

The formation of the gross urea nitrogen (urea and ammonia nitrogen) excreted in the urine is still an unsettled point. There are probably many ways in which it is formed in the body. That urea is a synthetic product of the amino-acids was long ago definitely established by Schultzen and $\mathrm{Nenki}^{22}$ and it has been proved that at least one aminoacid, really a diamino-acid, namely arginin, found in the intestine, can be inverted into urea by means of the ferment arginase (Kossel and Dakin ${ }^{23}$ ). This, however, does not represent all of the urea excreted in the urine. The most probable theory is that the amino-acids have their $\mathrm{NH}_{2}$ groups split off by desamidating ferments, taken to the liver by the portal circulation, and the liver synthetizes some to urea, the remaining portion being excreted as ammonia. The gross urea therefore represents very probably the desamidating capacity of the organism.

The urea nitrogen according to Morner and Sjoqvist makes up 72 to 76 per cent. of the total nitrogen excreted in the urine. In a year-old child Camerer found the urea nitrogen 72 to 76 per cent. of the total nitrogen, and in a 5-months-old breast baby 83 per cent. of the total nitrogen. In a case of mine a 5 -months-old breast baby excreted $0.5 \mathrm{gm}$. a day, or 72 to 75 per cent. of the total nitrogen, and when put on the

22. Schultzen and Nenki: Ber, d. deutsch. chem. Gesellsch., 1869, ii, 566.

23. Kossel and Dakin: Ztschr. f. physiol. Chemie, 1904, xli, 32. 
bottle this child excreted $0.6 \mathrm{gm}$. per day or 78 per cent. of the total nitrogen. L. F. Meyer and Ritschel state that the urea coefficient, that is, the percentage of urea nitrogen to total nitrogen, is from 60 to 80 per cent. Hoobler ${ }^{24}$ in a presumably normal bottle baby 9 months old, found the urea excretion 52 per cent. when fed on low fats, and 44 per cent. on high fats. This latter is probably due to the fact that there was a compensatory increase in the ammonia nitrogen. In an older child, 5 years of age, the urea nitrogen excretion was found by $S_{c h w a r z}{ }^{25}$ to be 6 to $7 \mathrm{gm}$. per day, or 87 per cent. of the total nitrogen. According to Folin ${ }^{28}$ the amount of urea excreted depends on the nature of the diet. He showed that in cases with a rich nitrogen diet such as eggs and milk, the urea nitrogen can be as high as 87 per cent. and with a nitrogen-free diet may be as low as 60 per cent.

Vogt ${ }^{27}$ showed that in acute gastro-enteritis the urea may be as low as 36 per cent. This, however, is not characteristic of acute gastroenteritis, for a low urea was also found in patients with marked malnutrition without acute intestinal disturbances. They did not seem to do well either on woman's milk or on cow's milk, probably due to an intolerance to fat. This effect of increased fat, or perhaps an intolerance to fat, is shown in Hoobler's case when put on a high fat mixture. Does this low urea excretion mean a disease of the liver? That this is the case in some instances is demonstrated in acute yellow atrophy and phosphorus poisoning in which there is a markedly decreased excretion of urea nitrogen. In gastro-enteritis, however, according to Thiemich, ${ }^{28}$ quoted from Vogt, the liver is damaged only in a small percentage of the cases and even in chronic nutritional disturbances there is no great destruction of liver parenchyma. Yet the histologic changes may have no bearing on the ability of an organ to perform its chemical functions.

\section{ONDETERMINED NITROGEN}

Before discussing the ammonia nitrogen, I will touch on the question of the undetermined nitrogen in the urine. As stated before, this figure is obtained roughly by adding the ammonia nitrogen to the urea nitrogen and subtracting this from the total nitrogen. ${ }^{29}$ In this undetermined nitrogen is included uric acid nitrogen, creatin and creatinin nitrogen, and purin body nitrogen, all of which will be discussed later. This nitrogen is unaffected by the amount of nitrogen ingested and is supposed by Folin and others to be the nitrogen product of a metabolism apart from

24. Hoobler: Arch. Pediat., 1910, xxvii, 856.

25. Schwarz: Jahrb. f. Kinderh., 1910, lxxii (Series 3, xxii, part 5).

26. Folin, O.: Am. Jour. Physiol., 1905, xiii, 45 and 116.

27. Monatsch. f. Kinderh., viii, No. 2.

28. Thiemich: Beitr. z. path. Anat. u. z. allg. Path., xx, 179.

29. I have done this in this portion of my paper because Vogt discusses the nitrogen partitions in the new-born in this manner. 
the other-an expression of the intermediary metabolism. Because of the decrease in the urea nitrogen mentioned above, we have an increase in the undetermined nitrogen, provided the ammonia nitrogen remains constant. Inasmuch as these children with acute and chronic intestinal disturbances are in a state of under-nutrition, it might be said that this diminished urea and high undetermined nitrogen is due to hunger. In adults and in children also, hunger decreases the urea nitrogen, it is true, but there is such a marked increase in the ammonia nitrogen, that when both are added together and subtracted from the total nitrogen we have no increase in the undetermined nitrogen. Vogt examined the nitrogen partition in the urine of new-born infants and was able to find two distinct classes; one with a percentile decrease in the urea and a corresponding percentile increase in the undetermined nitrogen; the other with a high urea and a low undetermined nitrogen. He found, for instance, 46 per cent. urea nitrogen and 44 per cent. undetermined nitrogen as compared with the total nitrogen. In other cases 81 per cent. urea nitrogen and 11 per cent. undetermined nitrogen. Whether this is due to an increase in the uric acid excretion in the one, or to a diathesis, it is impossible at the present moment to say. The increase or decrease in uric acid excretion, however, should not affect the urea; it might, though, make up the greater part of the undetermined nitrogen, and therefore not mean a decreased excretion of the aminoacids in the urine. It is interesting to note that in Hoobler's case on low and medium fats, the undetermined nitrogen was 4.6 per cent. of the total nitrogen, whereas on high fats there was 11.5 per cent. undetermined nitrogen in the urine. Whether this high undetermined nitrogen means a disability of the liver or other organs to form urea from amino-acids, is still an open question. The urea excretion in the many pathologic states in infancy has not been investigated. It would seem especially important to know the excretion of urea in various types of malnutrition. In three cases of rachitic dwarfism Schwarz ${ }^{30}$ found the excretion of urea normal as compared with a healthy child.

\section{AMMONIA NITROGEN}

Since the discovery by Keller ${ }^{31}$ that the ammonia nitrogen in the urine of children suffering from alimentary intoxication is greatly increased, intense interest has been manifested in the ammonia excretion in the infant's urine. The ammonia nitrogen co-efficient, that is, the percentage of ammonia nitrogen to total nitrogen, has been the subject of considerable investigation. In a five months' old breast baby Camerer

30. Schwarz: Jahrb. f. Kinderh., 1910, 1xxii, 724.

31. Keller: Jahrb. f. Kinderh., 1897, xliv, 55. 
found this co-efficient to be 7.7 per cent.; Keller, 7.7 to 12 per cent. Meyer and Langstein ${ }^{32}$ claimed that figures under 10 per cent. are normal. Amberg and Merrill ${ }^{33}$ found the ammonia nitrogen co-efficient in breast babies during the first few weeks of life to be from 4 to 12 per cent. During hunger the ammonia output in the urine increases and must not be confounded with an acidosis. Meyer and Langstein have noticed this increase already on the second day of hunger. Folin ${ }^{26}$ states that a decrease in the nitrogen intake enough to show a decrease in the nitrogen output in the urine will give an increase in the excretion of ammonia in the urine. Therefore, the ammonia excretion in the normal infant depends on the amount of nitrogen in the food. It has been generally understood that an increase of fat in the food alone caused an increase in the ammonia output. This was shown not to be absolutely the case by Amberg and Merrill, ${ }^{34}$ for if the proteins are increased with the increase in the fat there will be no increase in the ammonia output. It depends more or less on the relationship of the fat to the protein. They have shown in a breast-fed baby that if this relationship were kept at 3 to 1 the ammonia output was only 8 per cent. If, however, the fat was increased and not the protein, the ammonia excretion went up to 18 per cent. In Hoobler's ${ }^{24}$ case the ammonia nitrogen went up from 2 per cent. on a low fat to 15 per cent. on a high fat mixture, but in this experiment the protein remained about the same, only the fats being increased. From the foregoing it is easily seen that one must be very careful in judging an acidosis by the amount of ammonia excreted. However, the excretion of ammonia in the cases described by Keller went up to 30 or 40 per cent. of the total nitrogen. This is undoubtedly due to an acidosis. It might also be due to a disturbance in the formation of urea, but Keller ${ }^{35}$ found that by giving amino-acids such as glycocoll, leucin, and asparagin, there was no relative diminution in the excretion of urea. Pfaundler, ${ }^{36}$ on the other hand, thought it might be due to a disturbance in the liver and the formation of urea, on account of the fact that there was a diminished ability of the liver to oxidize salicyl aldehyd. However, the later researches of Stemitz, Keller and Freund proved it to be beyond a doubt due to an acidosis, the increased excretion of alkali taking place through the feces and the ammonia used to neutralize the acids formed.

32. Meyer and Langstein: Jahrb. f. Kinderh., 1906, liii, 30.

33. Amberg and Merrill: Jour. Biol. Chem., 1907, iii, 311.

34. Amberg and Merrill: Jahrb. f. Kinderh., lxix.

35. Keller: Centralbl. f. allg. Pathol. u. path. Anat., 1898, ix, 739.

36. Pfaundler: Jahrb. f. Kinderh., liv, 247. 


\section{NUCLEOPROTEIN}

Before taking up a consideration of the remaining nitrogen constituents of the urine it is important to know something of the breaking down of the nucleoprotein from which a greater part of this nitrogen comes. This nitrogen (uric acid, creatinin, etc.), as contradistinguished from the urea nitrogen, has absolutely no relation to the protein intake. Folin advanced the theory that there are two metabolisms going on, an exogenous and an endogenous. In the exogenous metabolism the organism takes care of the entire intake of nitrogen, with the exception of a small part which goes to the repletion of that nitrogen lost in the endogenous metabolism. This endogenous metabolism is, however, affected by the nucleoprotein intake and it is to this we must now turn our attention.

As stated in the beginning of the discussion, the nucleoproteins are a class of complex proteins and are found in food richly supplied with cells. They are made up of proteins and nucleic acids: Protein loosely combined, and protein very closely combined, with the nucleic acids, so that when they are taken into the stomach, the pepsin takes the loosely combined protein, forms peptones, albuminoses, polypeptids, and aminoacids. What is left is nucleic acids plus the closely combined proteins, together commonly called nucleins. The trypsin of the pancreatic juice then splits off the protein from the nuclein, and nucleic acids are left. These acids are, no doubt, also split up, but as yet there is only one known ferment that can do so, namely, nuclease, discovered by Sachs ${ }^{37}$ in 1905 . The pancreatic juice in addition has the property of changing the nucleic acids so as to render them more easily split up. They are broken up in the intestinal wall but not in the lumen of the intestines. Here they are resorbed, but just where they are changed into nucleoprotein of the body is unknown. Perhaps they are taken by the blood stream to the various organs, there combining with the nucleoprotein of the blood, forming the nucleoprotein of these organs. A portion of the nucleic acids is broken down by the intestinal bacteria, for purin bodies are found in the stools. ${ }^{38}$ They are derived, no doubt, from epithelium and bacteria.

Nucleic acids when split up result in the following:

1. Purin bases; guanin, adenin, xanthin and hypoxanthin.

2. Pyrimidin bases: thymin, cytosin, uracil.

3. Carbohydrate group (hexoses).

4. Phosphoric acid. 337.

37. Sachs, Fritz: Ueber die Nuelease, Ztschr. f. physiol. Chem., 1905, xlvi,

38. Kruger and Schittenhelm: Ztschr. f. physiol. Chem., 1905, xlv; 1902, $\operatorname{xxxv}, 153$. 
Guanin, a purin base, can be converted into xanthin by means of a ferment, and this in turn can be converted into uric acid. Adenin, on the other hand, can be changed into hypoxanthin by means of a ferment, this again into xanthin and then into uric acid. ${ }^{39}$ This shows the close connection which these nucleoproteins or nucleic acids have with the formation of uric acid. Jones thinks these changes are due to different ferments (guanase and adenase), but Schittenhelm believes them to be due to the same ferment.

\section{URIC ACID}

Uric acid represents the direct metabolism of the nucleoproteins in the food, and it is shown that its excretion is in direct relation to the amount of these bodies ingested. However, if a patient is given a nucleoprotein, or, as it is called, a purin-free diet, he will still excrete a small quantity of uric acid, which is exceedingly constant for the same individual. Burlan and Schur, ${ }^{40}$ who first pointed this out, called this the endogenous uric acid. The increased excretion found on giving purin bodies they called the exogenous uric acid. Now, just where does this endogenous uric acid come from? Burean ${ }^{41}$ showed that during muscular exercise there is an increased excretion of purin bases in the urine, and soon after of uric acid. He thinks, therefore, that it is formed in the muscles. But it has been shown by Schittenhelm that part of the uric acid thus formed can be destroyed by a ferment which he called the "urikolytic ferment." Therefore, the amount of uric acid excreted is not necessarily all that is formed in the body. If decreased or increased in the urine it can only be interpreted as to whether more is destroyed or less formed. If the former is the case, then the substances into which uric acid is split up should be increased in the urine. Some of these substances, such as glycocoll, oxalic acid and allantoin have been found. A discussion of these, however, would take us too far afield. Yet a search for these substances is of importance as allantoin has been found in the urine of the newly-born by Gusserow. ${ }^{42}$

The excretion of uric acid is especially interesting in the infant, for it receives a food which is purin-free, except during the first few days of life. In order to add nucleoprotein to its body, then, it must be able synthetically to produce these, and it has been shown by experi-

39. Werner, Hugo: Ergebnisse der Physiologie der Harnsäure, 1902, i, Abt. p. 555; Schittenhelm, A.: Die Purinkörper, ete., Ztschr. f. Stoffwechs. u. Verdauungskr., 1904, v, 226; Burean, Richard: Med. Klin., 1905, i, 131; ii, No. 19-21; Mendel: Harvey Society Lecture, Feb. 10, 1906.

40. Burean, Richard, and Schur, Hyman: Arch. f. d. ges. Physiol. (Pflüger's), Bonn, 1900, lxxx, 241; 1901, lxxxvii, 239; Rockwood: Am. Jour. Physiol., 1905, xii, 38.

4l. Burean: Ztschr. f. physiol. Chem., 1905, xliii, 494.

42. Gusserow: Arch. f. Gynäk. Berl., 1872, iii, 270. 
ment on the lower animals that the organism is able to produce nucleoproteins even if kept on a purin-free diet from birth. According to Orgler $^{43}$ a breast-fed infant excretes 30 to $40 \mathrm{mg}$. of uric acid; an artificially-fed one, 70 to $90 \mathrm{mg}$., the retention being greater in the breast-fed. It makes up about 3 to 5 per cent. of the total nitrogen in the urine.

Jable 8.-Uric Acid Excretion in Ixfants. Total in Three-Day Experlanents (ORGLER)

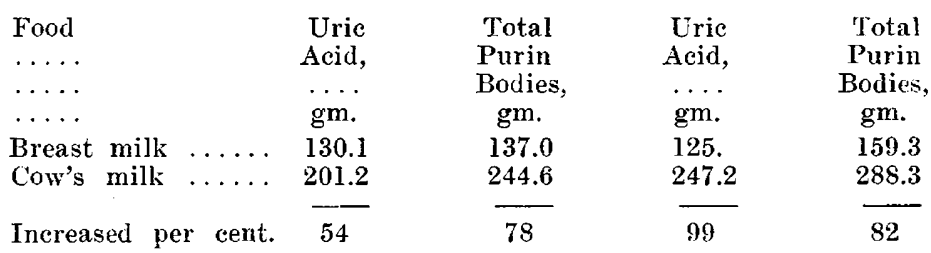

As noted before, an increase in the nitrogen intake with a purin-free diet does not increase the uric acid excretion. The addition of carbohydrate to the food, however, according to Orgler, reduces the amount of uric acid excreted and there is an increased retention. If this increase in the carbohydrate is continued, the amount of uric acid excreted will increase slightly, but not to the quantity that it was at the beginning of the experiment. As observed before, the addition of carbohydrate to the diet causes an increased retention of nitrogen and with this increased retention of nitrogen an increase in the retention of uric acid, and protein is added to the body with a resulting increase in weight and growth. Were this retention of nitrogen any better in the breast-fed than in the artificially-fed child this might explain the small excretion of uric acid in the former and a correspondingly greater and more steady increase in weight in the breast-fed. Inasmuch as this is not the case one cannot ascribe the greater protein increase to this fact. The nucleoprotein however has a phosphorus and iron group, and it has been shown by Krasnogorsky ${ }^{44}$ that the absolute retention of iron is much better in the breast-fed than in the artificially-fed. Orgler thinks this may be the reason that more purin is added to the body of the breast-fed baby than to the one artificially fed, even though the retention of nitrogen is the same. Concerning the uric acid output in the new-born, conditions are somewhat different. Schloss and Crawford ${ }^{9}$ have shown that the output is absolutely and relatively high, being greatest in the first three days of life. It is out of all proportion to the amount of purin bases in the colostrum and is greater when the cord is ligated late. They found the excretion to vary from 60 to 100

43. Orgler: Ueber Harnsïure ausscheidung im Säuglingsalter, Jahrb. f. Kinderh., 1908, lxvii, 383 .

44. Krasnogorsky: Jahrb. f. Kinderh., 1906, lxiv. 
mg. of uric acid nitrogen per day the first four days of life, 30 to $40 \mathrm{mg}$. per day in the second four days of life-20 to $30 \mathrm{mg}$. per kilo weight during the first four days, 8 to $10 \mathrm{mg}$. per kilo the second four days of life. Uric acid nitrogen made up from 18 to 20 per cent. of the total nitrogen during the first three days of life. Schloss and Crawford seemed to think that the greater excretion of uric acid in the late ligation cases points to the cellular elements of the blood as the origin of this uric acid. This theory is strengthened, perhaps, by the fact that in a case of Schwarz's ${ }^{45}$ the uric acid in the urine was greatly increased in a baby 11 days old immediately after a transfusion, being 25 per cent. of the total nitrogen.

\section{CREATININ AND CREATIN}

The excretion of creatinin and creatin in the urine is still under considerable discussion. Whether one is derived from the other or not, or just where the creatin is changed to creatinin, is unknown. In the adult, creatinin is constantly present in normal urines and creatin is rarely if ever present. During febrile states, or in cases of fasting or in negative nitrogen balance, creatinin may be increased in urine, and creatin may be present in varying quantities, even greater than creatinin. ${ }^{25}$ Creatin is normally found in the muscles, which are supposed to be the depot for the body. Creatinin, however, is not found in muscles. The ingestion of creatin does not increase the excretion of creatinin in the urine $\left(F_{0} l_{i n}{ }^{46}\right)$. The protein intake does not affect the amount of creatinin in the urine and this excretion is remarkably constant in normal individuals under similar conditions. (Folin, Hoogenhuyze and Verploegh ;57 Wolff and Shaffer ${ }^{47}$ and Shaffer. ${ }^{49}$ ) Folin believes that the creatinin nitrogen co-efficient is an indicator of endogenous nitrogen metabolism, while Shaffer more specifically thinks it is an expression of the endogenous muscular metabolism. Folin further showed that the amount of creatinin excreted depended on the weight of the subject and more explicitly on the amount of muscular weight, or, as Shaffer puts it, "active protoplasmic tissues." In the adult Folin found the creatinin excretion to be 20 to $24 \mathrm{mg}$. per kilo body weight and Shaffer 18 to $30 \mathrm{mg}$. per kilo. In a boy of 5 Schwarz found 6.1 to $7.7 \mathrm{mg}$. per kilo weight-150 to $160 \mathrm{mg}$. in twenty-four hours. Amberg and Merrell ${ }^{33}$ found 26 to $39 \mathrm{mg}$. excreted in the urine of infants, or 6.7 to $9.9 \mathrm{mg}$. creatin nitrogen per kilo body weight. These were children beyond the period of physiologic loss. It is

45. Schwarz and Ottenberg: Am. Jour. Med. Sc., July, 1910.

46. Folin: Jour. Biol. Chem., Am. Jour. Physiol., 1905.

47. Folin, Hoogenhuyze and Verploegh: Ztschr. f. Physiol., xxiii, 1.

48. Wolf and Schaffer: Jour. Biol. Chem., 1908, p. 439.

49. Schaffer: Am. Jour. Physiol., xxii, 445. 
especially interesting to note the figures for the first few days of life. This Sedgwick ${ }^{50}$ has done in seven cases during the first few days of life. It varied considerably with the amount of urine excreted and as the weight is not included in his table it is impossible to reckon the creatinin co-efficient. The excretion was up to $25 \mathrm{mg}$. creatinin in twenty-four hours. Sedgwick was further able to demonstrate the presence of creatinin in the amniotic fluid.

\section{AMINO-ACIDS}

Embden and Reese ${ }^{51}$ and Plaut and Reese ${ }^{52}$ found glycocoll in normal urine and only faint traces of other amino-acids. Abderhalden and Schittenhelm, ${ }^{53}$ on the other hand, did not find them in the urine unless there was a disturbance in the protein metabolism. Samuely ${ }^{54}$ found glycocoll in the normal urine of two new-born infants. Langstein and Reitschel ${ }^{55}$ did not find any amino-acids in normal urine. Von Reuss ${ }^{56}$ found glycocoll in the urine of infants without relation to age or food. Schultz, ${ }^{57}$ using Sorenson's method modified by Frey and Gigon, examined the urine of infants on the breast and on cow's milk, and found 8.5 per cent. amino-acid nitrogen to total nitrogen in the former and 6.7 per cent. amino-acid nitrogen in the latter. These figures are fairly constant for the same child but vary greatly in different children, both in health and disease. In cases of children very much under weight from alimentary disturbances but well at the time of examination, the amino-acid nitrogen in the urine was from 6.7 to 8.5 per cent. In cases of dyspepsia ("Bilanzstörung" of Finkelstein) the amino-acid nitrogen was from 8.5 to 10 per cent.

50 East Ninety-First Street.

50. Sedgwick: Creatinin Metabolism, Jour. Am. Med. Assn., 1910, lv, 1178.

51. Embden and Reese: Beitr. z. chem. Phys. u. Path. (Hofmeister), vii, 441.

52. Plaut and Reese: Beitr. z. chem. Phys. u. Path. (Hofmeister), vii, 425.

53. Abderhalden and Schittenhelm: Ztschr. f. phys. Chemie, xlvii, 343.

54. Samuely: Ztschr. f. phys. Chemie, xlvii, 376.

55. Langstein and Reitschel: Biochem Ztschr., i, 75.

56. Von Reuss: Wien. klin. Wehnschr., 1909, p. 158.

57. Schultz: Jahrb. f. Kinderh., 1910, Ixxii. 